\title{
QM-HiFSA-Aided Structure Determination of Succinilenes A-D, New Triene Polyols from a Marine-Derived Streptomyces sp.
}

\author{
Munhyung Bae ${ }^{1}$, So Hyun Park ${ }^{1}$, Yun Kwon ${ }^{1}$, Sang Kook Lee ${ }^{1}$, Jongheon Shin ${ }^{1}$, \\ Joo-Won Nam ${ }^{2,3, *}$ and Dong-Chan $\mathrm{Oh}^{1, *}$ \\ 1 Natural Products Research Institute, College of Pharmacy, Seoul National University, Seoul 08826, Korea; \\ baemoon89@snu.ac.kr (M.B.); hanirela@snu.ac.kr (S.H.P.); kisi2016@snu.ac.kr (Y.K.); \\ sklee61@snu.ac.kr (S.K.L.); shinj@snu.ac.kr (J.S.) \\ 2 College of Pharmacy, Yeungnam University, Gyeongsan, Gyeongbuk 38541, Korea \\ 3 Department of Medicinal Chemistry \& Pharmacognosy, College of Pharmacy, \\ University of Illinois at Chicago, Chicago, IL 60612, USA \\ * Correspondence: jwnam@yu.ac.kr (J.-W.N.); dongchanoh@snu.ac.kr (D.-C.O.); \\ Tel.: +82-53-810-2818 (J.-W.N.); +82-2-880-2491 (D.-C.O.); \\ Fax: +82-53-810-4654 (J.-W.N.); +82-2-762-8322 (D.-C.O.)
}

Academic Editors: Tadeusz Molinski and John MacMillan Received: 14 January 2017; Accepted: 8 February 2017; Published: 14 February 2017

\begin{abstract}
Based on profiles of secondary metabolites produced by marine bacteria obtained using LC/MS, succinilenes A-D (1-4), new triene polyols, were discovered from a culture of a Streptomyces strain SAK1, which was collected in the southern area of Jeju Island, Republic of Korea. The gross structures of 1-4 were primarily determined through analysis of NMR spectra. The double bond geometries of the succinilenes, which could not be established from conventional ${ }^{1} \mathrm{H}$ NMR spectra because of the highly overlapped olefinic signals, were successfully deciphered using the recently developed quantum-mechanics-driven ${ }^{1} \mathrm{H}$ iterative full spin analysis (QM-HiFSA). Succinilenes A-C (1-3) displayed inhibitory effects against lipopolysaccharide (LPS)-induced nitric oxide (NO) production, indicating their anti-inflammatory significance. These three compounds (1-3) commonly bear a succinic acid moiety, although succinilene D (4), which did not inhibit NO production, does not have this moiety in its structure. The absolute configurations of succinilenes A-D (1-4) were established through J-based configuration analysis, the modified Mosher's method following methanolysis, and CD spectral analysis.
\end{abstract}

Keywords: marine actinomycete; QM-HiFSA; NMR; anti-inflammatory

\section{Introduction}

Precise interpretation of the spectroscopic data of molecules is the critical step in natural product research for drug discovery. Nuclear magnetic resonance (NMR) spectroscopy is a predominant method used to elucidate the structures of natural products. However, NMR spectra, even when acquired at a high magnetic field, are sometimes misinterpreted or hardly interpretable due to a lack of signal dispersion or the occurrence of higher order effects. Quantum-mechanics-driven ${ }^{1} \mathrm{H}$ iterative full spin analysis (QM-HiFSA) [1] is an emerging NMR interpretation tool that can reduce errors and ambiguities in the analysis of highly overlapped ${ }^{1} \mathrm{H}$ NMR spectra. HiFSA allows for the complete and precise interpretation of ${ }^{1} \mathrm{H}$ NMR parameters such as coupling constants $\left(J_{\mathrm{HH}}\right)$, chemical shifts $\left(\delta_{\mathrm{H}}\right)$, and line widths $\left(\Delta v_{1 / 2}\right)$, on the basis of both structural and spectral line shape considerations [2,3].

Similar to the importance of using combinations of chemical and computational analyses, it is critical to focus on prolific sources of structurally and biologically novel compounds because of 
the constant clinical need for new chemical entities with pharmaceutical potential [4]. As part of our efforts to discover new bioactive natural products, we have been investigating the chemistry of actinobacteria derived from marine and saline environments including salterns [5-7], intertidal zones [8-11], and deep-sea sediments [12]. In our previous reports, novel bioactive secondary metabolites were mainly identified through the chemical profiling of bacterial secondary metabolites by LC/MS analysis. Based on this approach and focusing on actinobacterial chemical profiles, we have continuously isolated actinomycete strains from the southern area of Jeju Island, Republic of Korea. Our comprehensive time-course chemical screening of the marine actinomycete strain collection resulted in the discovery of Streptomyces strain SAK1, which was revealed to produce a series of previously-unreported secondary metabolites, each bearing a triene moiety ( $\mathrm{UV} \lambda_{\max }$ at $270 \mathrm{~nm}$ ), in the exponential phase of the culture (in 2 3 days after inoculation). Because the strain SAK1 interestingly produced tripartilactam [13] and sceliphrolactam [14], macrocyclic lactams originally reported from insect-associated Streptomyces strains, and the triene-bearing compounds disappeared as reaching the stationary phase of the culture on day 4 , a precise time-course study of the culture was performed to maximize the production of these new metabolites. Through a large-scale fermentation of this strain and the isolation of these compounds using High Performance Liquid Chromatography (HPLC), four new triene polyol metabolites, succinilenes A-D (1-4), with inhibitory activities against lipopolysaccharide (LPS)-induced nitric oxide (NO) production were obtained. The gross structures of these new compounds were elucidated by conventional 1D and 2D NMR spectroscopy. However, their overlapped ${ }^{1} \mathrm{H}$ NMR signals, especially in the olefinic region, required the application of QM-HiFSA to determine the geometries of their triene moieties. Herein, we report the isolation, structure elucidation, and biological activities of succinilenes A-D (1-4) (Figure 1), emphasizing a successful application of the QM-HiFSA technique for the complete assignment of ${ }^{1} \mathrm{H}-{ }^{1} \mathrm{H}$ coupling constants, even from complicated high-order ${ }^{1} \mathrm{H}$ peaks.

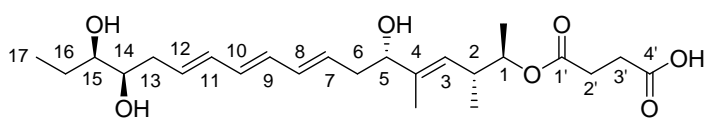

1

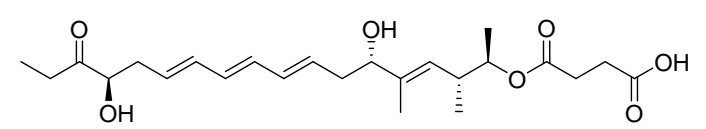

3

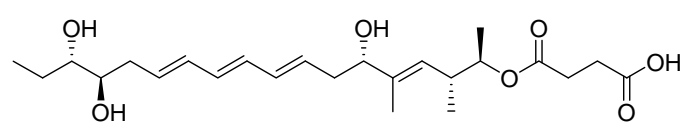

2

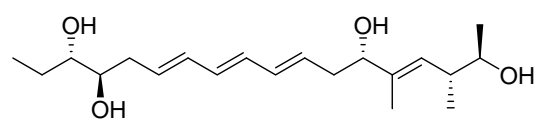

Figure 1. Structures of succinilenes A-D (1-4).

\section{Results}

\subsection{Structural Elucidation}

Succinilene A (1) was isolated as a yellow gum, and its molecular formula was deduced as $\mathrm{C}_{24} \mathrm{H}_{38} \mathrm{O}_{7}$ based on HR-FAB mass spectrometry (obsd. $[\mathrm{M}-\mathrm{H}]^{-}$at $m / z$ 437.2550, calcd. $[\mathrm{M}-\mathrm{H}]^{-}$ 437.2539) in combination with ${ }^{1} \mathrm{H}$ and ${ }^{13} \mathrm{C}$ NMR data (Table 1). The ${ }^{1} \mathrm{H}$ NMR spectrum of $\mathbf{1}$ in pyridine- $d_{5}$ exhibited typical signatures of polyenes and polyols, with seven olefinic protons $\left(\delta_{\mathrm{H}} 6.3664\right.$, $6.3158,6.2929,6.2885,6.1280,5.9506$, and 5.5426) and four protons attached to oxygen-bearing carbons $\left(\delta_{\mathrm{H}} 5.0898,4.3745,3.9176\right.$, and 3.7579). Further analysis of the ${ }^{1} \mathrm{H}$ NMR spectrum of 1 revealed the existence of eleven aliphatic protons between $\delta_{\mathrm{H}} 2.9046$ and 1.8105, a singlet methyl group bound to an olefinic carbon $\left(\delta_{\mathrm{H}} 1.8616\right)$, two doublet methyl groups $\left(\delta_{\mathrm{H}} 1.1907\right.$ and 0.9973$)$, and a triplet methyl group $\left(\delta_{\mathrm{H}} 1.1619\right)$ bound to an $s p^{3}$ aliphatic carbon. The ${ }^{13} \mathrm{C}$ and gradient heteronuclear single quantum coherence spectroscopy (gHSQC) NMR data displayed two carbonyl carbons ( $\delta_{\mathrm{C}} 175.7$ and 172.7), seven olefinic $s p^{2}$ carbons $\left(\delta_{C} 132.8,132.6,132.5,132.0,131.7,131.6\right.$, and 127.2$)$, one quaternary olefinic 
carbon $\left(\delta_{C} 140.1\right)$, four oxygen-bound methine carbons $\left(\delta_{C} 76.8,75.5,74.2\right.$, and 74.1$)$, six aliphatic carbons $\left(\delta_{\mathrm{C}} 39.8,38.0,37.1,30.4,30.3\right.$, and 27.5$)$, and four methyl group carbons $\left(\delta_{\mathrm{C}} 17.2,16.6,12.2\right.$, and 10.9). Based on the UV absorption maximum at $270 \mathrm{~nm}$ and the eight olefinic carbon signals, succinilene A (1) was expected to bear three conjugated double bonds and an isolated double bond. These four double bonds along with two carbonyl functional groups accounted for all of the six double bond equivalents inherently calculated from the molecular formula, thus indicating that succinilene A (1) is a linear compound.

Table 1. NMR data for 1 and 2 in pyridine- $d_{5}$.

\begin{tabular}{|c|c|c|c|c|c|c|}
\hline \multirow{2}{*}{ Position } & \multicolumn{3}{|c|}{1} & \multicolumn{3}{|c|}{2} \\
\hline & $\delta_{H}{ }^{a}$ & Mult $(J$ in $\mathrm{Hz})$ & $\delta_{C}^{b}$ & $\delta_{H}{ }^{c}$ & Mult $(J$ in $\mathrm{Hz})$ & $\delta_{C}^{d}$ \\
\hline 1 & 5.0898 & $\mathrm{dq}(6.35,5.50)$ & $74.1, \mathrm{~d}$ & 5.0882 & $\mathrm{dq}(6.35,5.75)$ & $74.1, \mathrm{~d}$ \\
\hline 1-Me & 1.1907 & $\mathrm{~d}(6.35)$ & $17.2, \mathrm{q}$ & 1.1862 & $\mathrm{~d}(6.35)$ & $17.2, \mathrm{q}$ \\
\hline 2 & 2.7397 & $\operatorname{ddq}(9.74,6.82,5.50)$ & $37.1, \mathrm{~d}$ & 2.7356 & $\mathrm{ddq}(9.60,6.76,5.75)$ & $37.2, \mathrm{~d}$ \\
\hline 2-Me & 0.9973 & $\mathrm{~d}(6.82)$ & $16.6, \mathrm{q}$ & 0.9916 & $\mathrm{~d}(6.76)$ & $16.7, \mathrm{q}$ \\
\hline 3 & 5.5426 & $\mathrm{~d}(9.74)$ & $127.2, \mathrm{~d}$ & 5.5359 & $\mathrm{~d}(9.60)$ & $127.2, \mathrm{~d}$ \\
\hline 4 & - & - & $140.1, \mathrm{~s}$ & - & - & $140.1, \mathrm{~s}$ \\
\hline 4-Me & 1.8616 & $\mathrm{~s}$ & $12.2, \mathrm{q}$ & 1.8618 & $\mathrm{~s}$ & $12.1, \mathrm{q}$ \\
\hline 5 & 4.3745 & $\mathrm{dd}(7.04,6.04)$ & $76.8, \mathrm{~d}$ & 4.3721 & dd $(6.69,6.34)$ & $76.9, \mathrm{~d}$ \\
\hline \multirow[t]{2}{*}{6} & 2.6519 & ddd $(-14.00,7.30,7.04)$ & $39.8, \mathrm{t}$ & 2.6498 & ddd $(-14.11,7.47,6.69)$ & $39.8, \mathrm{t}$ \\
\hline & 2.5631 & ddd $(-14.00,7.50,6.04)$ & & 2.5587 & ddd $(-14.11,7.10,6.34)$ & \\
\hline 7 & 5.9506 & ddd $(14.65,7.50,7.30)$ & $132.0, \mathrm{~d}$ & 5.9395 & ddd $(14.81,7.47,7.10)$ & $131.9, \mathrm{~d}$ \\
\hline 8 & 6.2885 & dd $(14.65,10.77)$ & $132.5, \mathrm{~d}$ & 6.2814 & dd $(14.81,10.73)$ & $132.6, \mathrm{~d}$ \\
\hline 9 & 6.2929 & dd $(14.03,10.77)$ & 131.6, d & 6.2773 & dd $(14.79,10.73)$ & $131.6, \mathrm{~d}$ \\
\hline 10 & 6.3158 & dd $(14.03,10.49)$ & 131.7, d & 6.3179 & $\mathrm{dd}(14.79,10.53)$ & 131.7, d \\
\hline 11 & 6.3664 & dd $(15.19,10.49)$ & $132.6, \mathrm{~d}$ & 6.3913 & dd $(15.19,10.53)$ & $132.7, \mathrm{~d}$ \\
\hline 12 & 6.1280 & ddd $(15.19,7.50,7.12)$ & $132.8, \mathrm{~d}$ & 6.2145 & ddd $(15.19,7.45,7.24)$ & $133.0, \mathrm{~d}$ \\
\hline \multirow[t]{2}{*}{13} & 2.7253 & ddd $(-14.36,7.50,4.66)$ & $38.0, \mathrm{t}$ & 2.8829 & ddd $(-14.13,7.24,3.36)$ & $37.5, \mathrm{t}$ \\
\hline & 2.6745 & ddd $(-14.36,8.02,7.12)$ & & 2.7481 & ddd $(-14.13,8.12,7.45)$ & \\
\hline 14 & 3.9176 & ddd $(8.02,4.66,4.33)$ & $74.2, \mathrm{~d}$ & 4.0324 & ddd $(8.12,5.84,3.36)$ & $74.9, \mathrm{~d}$ \\
\hline 15 & 3.7579 & ddd $(8.68,4.33,3.88)$ & $75.5, \mathrm{~d}$ & 3.8871 & $\operatorname{ddd}(8.72,5.84,2.69)$ & $76.1, \mathrm{~d}$ \\
\hline \multirow[t]{2}{*}{16} & 1.8578 & $\mathrm{ddq}(-13.87,7.38,3.88)$ & $27.5, \mathrm{t}$ & 2.0541 & $\mathrm{ddq}(-13.61,7.36,2.69)$ & $26.5, \mathrm{t}$ \\
\hline & 1.8105 & $\operatorname{ddq}(-13.87,8.68,7.49)$ & & 1.8504 & $\mathrm{ddq}(-13.61,8.72,7.42)$ & \\
\hline 17 & 1.1619 & dd $(7.49,7.38)$ & $10.9, \mathrm{q}$ & 1.2234 & $\mathrm{dd}(7.42,7.36)$ & $10.9, \mathrm{q}$ \\
\hline $\mathbf{1}^{\prime}$ & - & - & $172.7, \mathrm{~s}$ & - & - & $173.0, \mathrm{~s}$ \\
\hline \multirow[t]{2}{*}{$2^{\prime}$} & 2.8516 & ddd $(-11.48,7.29,6.04)$ & $30.3, \mathrm{t}$ & 2.8496 & ddd $(-18.10,7.13,6.33)$ & $30.6, \mathrm{t}$ \\
\hline & 2.8436 & ddd $(-11.48,7.54,5.82)$ & & 2.8496 & ddd $(-18.10,8.56,4.83)$ & \\
\hline \multirow[t]{2}{*}{$3^{\prime}$} & 2.9046 & ddd $(-16.39,7.29,5.82)$ & $30.4, \mathrm{t}$ & 2.9078 & ddd $(-15.38,8.56,7.13)$ & $30.8, \mathrm{t}$ \\
\hline & 2.8954 & ddd $(-16.39,7.54,6.04)$ & & 2.9022 & ddd $(-15.38,6.33,4.83)$ & \\
\hline $4^{\prime}$ & - & - & $175.7, \mathrm{~s}$ & - & - & $176.2, \mathrm{~s}$ \\
\hline
\end{tabular}

${ }^{\mathrm{a}} 900 \mathrm{MHz} ;{ }^{\mathrm{b}} 150 \mathrm{MHz} ;{ }^{\mathrm{c}} 600 \mathrm{MHz} ;{ }^{\mathrm{d}} 150 \mathrm{MHz}$. The $\delta_{\mathrm{H}}$ (in ppm) and $J$ (in $\mathrm{Hz}$ ) values were determined by HiFSA.

Given this information, all ${ }^{13} \mathrm{C}-{ }^{1} \mathrm{H}$ one-bond correlations were assigned by analysis of the gHSQC NMR spectrum (Table 1). Interpretation of COSY and HMBC NMR spectroscopic data readily led to the elucidation of the gross structure of succinilene A (1). First, the COSY signals from a terminal triplet methyl group $\left(\mathrm{H}_{3}-17\right.$ at $\left.\delta_{\mathrm{H}} 1.1619\right)$ to aliphatic methylene protons $\left(\mathrm{H}_{2}-16\right.$ at $\delta_{\mathrm{H}} 1.8578$ and 1.8105$)$ connected C-17 $\left(\delta_{\mathrm{C}} 10.9\right)$ to $\mathrm{C}-16\left(\delta_{\mathrm{C}} 27.5\right)$. The aliphatic carbon C-16 was elucidated to be directly connected to the oxygenated carbon C-15 $\left(\delta_{\mathrm{C}} 75.5\right)$ based on the COSY correlations between $\mathrm{H}-15$ $\left(\delta_{\mathrm{H}} 3.7579\right)$ and $\mathrm{H}-16$. The homonuclear correlation between $\mathrm{H}-15$ and $\mathrm{H}-14\left(\delta_{\mathrm{H}} 3.9176\right)$ revealed that an oxygen-bound methine carbon (C-14 at $\left.\delta_{\mathrm{C}} 74.2\right)$ was connected to $\mathrm{C}-15$, indicating the existence of a diol moiety. Further COSY analysis verified the connectivity between $\mathrm{H}-14$ and $\mathrm{H}_{2}-13\left(\delta_{\mathrm{H}} 2.7253\right.$ and 2.6745), identifying the C-14-C-13 bond. The aliphatic carbon C-13 was connected to the $s p^{2}$ carbon $\mathrm{C}-12\left(\delta_{\mathrm{C}} 132.8\right)$ based on a 3-bond ${ }^{1} \mathrm{H}-{ }^{1} \mathrm{H}$ coupling signal between $\mathrm{H}-12\left(\delta_{\mathrm{H}} 6.1280\right)$ and $\mathrm{H}-13$. Additional COSY correlations among the six olefinic protons from H-12 to H-7 $\left(\delta_{\mathrm{H}} 5.9506\right)$ indicated 
the construction of a triene moiety from C-12 to C-7 $\left(\delta_{\mathrm{C}} 132.8\right.$ to 132.0$)$, which is consistent with the UV absorption maximum at $270 \mathrm{~nm}$. The triene moiety was located next to C- 6 based on the ${ }^{3} J_{\mathrm{HH}}$ couplings between $\mathrm{H}_{2}-6\left(\delta_{\mathrm{H}} 2.6519\right.$ and 2.5631) and $\mathrm{H}-7$. The homonuclear correlations of $\mathrm{H}_{2}-6$ with the oxygenated proton $\left(\mathrm{H}-5\right.$ at $\left.\delta_{\mathrm{H}} 4.3745\right)$ showed C-6-C-5 $\left(\delta_{\mathrm{C}} 76.8\right)$ connectivity. The HMBC correlations from a singlet methyl proton $\left(\mathrm{H}_{3}-4-\mathrm{Me} ; \delta_{\mathrm{H}} 1.8616\right)$ to $\mathrm{C}-5, \mathrm{C}-4\left(\delta_{\mathrm{C}} 140.1\right)$, and $\mathrm{C}-3\left(\delta_{\mathrm{C}} 127.2\right)$ indicated expansion of the chain from $\mathrm{C}-5$ to $\mathrm{C}-3$ through $\mathrm{C}-4$. The olefinic methine $\mathrm{C}-3$ was assigned next to $\mathrm{C}-2\left(\delta_{\mathrm{C}} 37.1\right)$, with a branched methyl group $\left(\mathrm{H}_{3}-2-\mathrm{Me} ; \delta_{\mathrm{H}} 0.9973 / \delta_{\mathrm{C}} 16.6\right)$ attached to C-2. The COSY correlation from $\mathrm{H}-1\left(\delta_{\mathrm{H}} 5.0898\right)$ to $\mathrm{H}-2$ and $\mathrm{H}_{3}-1-\mathrm{Me}$ identified the connectivity of $\mathrm{C}-1\left(\delta_{\mathrm{C}} 74.1\right)$ and C-2, establishing the first partial structure from C-17 to C-1, a chain composed of 20 carbons bearing three hydroxyl groups and a treiene moiety. Based on additional 2D NMR analysis, the aliphatic $\mathrm{H}_{2}-2^{\prime}\left(\delta_{\mathrm{H}} 2.8516\right.$ and 2.8436) displayed ${ }^{3} J_{\mathrm{HH}}$ and ${ }^{3} J_{\mathrm{CH}}$ correlations to adjacent aliphatic $\mathrm{H}_{2}-3^{\prime}$ peaks $\left(\delta_{\mathrm{H}} 2.9015\right.$, and 2.8990) and two carbonyl carbons $\mathrm{C}-1^{\prime}$ and $\mathrm{C}-4^{\prime}\left(\delta_{\mathrm{C}} 172.7\right.$ and 175.7$)$, completing the second partial structure as a succinic acid. These two partial structures were connected based on a key HMBC correlation from H-1, of which the deshielded chemical shift $\left(\delta_{\mathrm{H}} 5.0898\right)$ was indicative for the existence of an ester linkage, to $C-1^{\prime}$, resulting in the gross structure of $\mathbf{1}$ (Figure 2a).
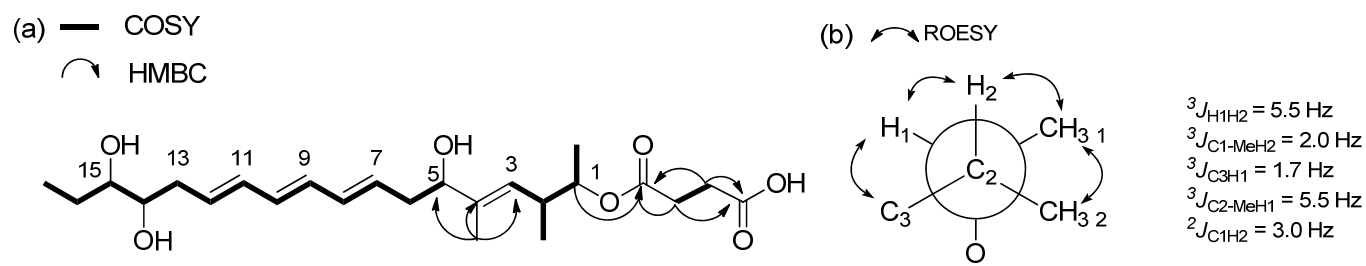

Figure 2. (a) Determination of the planar structure of succinilene A based on the analysis of key COSY and HMBC correlations; (b) J-based configuration analysis of succinilene A (1) at C-1 and C-2.

Succinilene B (2) was obtained as a yellow gum. The molecular formula was determined as $\mathrm{C}_{24} \mathrm{H}_{38} \mathrm{O}_{7}$ on the basis of HR-FABMS data (obsd. $[\mathrm{M}-\mathrm{H}]^{-}$at $m / z$ 437.2550, calcd. [M - H] $]^{-} 437.2539$ ) along with ${ }^{1} \mathrm{H}$ and ${ }^{13} \mathrm{C}$ NMR spectroscopic data (Table 1). The molecular formula and the UV spectrum of $\mathbf{2}$ were identical to those of $\mathbf{1}$, indicating that succinilene B (2) is structurally analogous to succinilene A (1). The 1D and 2D NMR data of $\mathbf{2}$ also displayed very similar patterns to those of $\mathbf{1}$, as expected. Further analysis of NMR spectroscopic data resulted in the construction of the gross structure of 2, which was identical to that of $\mathbf{1}$. Actually, most of the ${ }^{13} \mathrm{C}$ chemical shifts of $\mathbf{2}$ were very similar to those of $\mathbf{1}$, within $0.2 \mathrm{ppm}$. However, the ${ }^{13} \mathrm{C}$ peaks of $\mathrm{C}-13$ to $\mathrm{C}-16$ around the oxymethine group located adjacent to the terminal ethyl group differed by $0.5 \sim 1 \mathrm{ppm}$ compared to the same peaks in 1 , indicating that succinilene B (2) is a diastereomer of $\mathbf{1}$ that possesses different stereochemistry at C-13 or/and C-14.

Succinilene C (3) was purified as a yellow gum and determined to possess a molecular formula of $\mathrm{C}_{24} \mathrm{H}_{36} \mathrm{O}_{7}$ on the basis of HR-FABMS data (obsd. [M+H] ${ }^{+}$at $m / z$ 437.2562, calcd. $[\mathrm{M}+\mathrm{H}]^{+} 437.2545$ ) combined with ${ }^{1} \mathrm{H}$ and ${ }^{13} \mathrm{C}$ NMR spectral data (Table 2). Based on the molecular weight and UV spectrum of 3, it was expected that one of the hydroxyl groups in succinilene C (3) had been oxidized to a ketone group. According to the comparison of the 1D and 2D NMR spectroscopic data of 3 with those of $\mathbf{1}$, the oxygen-bound proton $\left(\mathrm{H}-15, \delta_{\mathrm{H}} 3.7579\right)$ in $\mathbf{1}$ was absent in 3 , and a ketone carbon signal $\left(\delta_{\mathrm{C}} 214.0\right)$ was detected instead, clarifying that the hydroxyl group at the C-15 position in $\mathbf{1}$ had been oxidized to the ketone group in 3 . This assignment was also supported by the 3-bond HMBC correlations from $\mathrm{H}_{3}-17\left(\delta_{\mathrm{H}} 1.0890\right)$ and $\mathrm{H}_{2}-13\left(\delta_{\mathrm{H}} 2.7803\right.$ and 2.6591$)$ to $\mathrm{C}-15$ and $\mathrm{H}_{3}-17 / \mathrm{H}-16$ and $\mathrm{H}_{2}-13 / \mathrm{H}-14$ COSY correlations.

Succinilene D (4) was isolated as a yellow gum, and its molecular formula was deduced to be $\mathrm{C}_{20} \mathrm{H}_{34} \mathrm{O}_{4}$ based on the corresponding HR-FABMS data (obsd. $[\mathrm{M}+\mathrm{Na}]^{+}$at $\mathrm{m} / z$ 361.2347, calcd. $\left.[\mathrm{M}+\mathrm{Na}]^{+} 361.2355\right)$ and ${ }^{1} \mathrm{H}$ and ${ }^{13} \mathrm{C}$ NMR spectroscopic data (Table 2). The molecular weight of 4 was 100 Da lower than those of $\mathbf{1}$ and $\mathbf{2}$, possibly indicating that the terminal succinic acid moiety 
in 1 and 2 might have been cleaved. Through the careful analysis of the 1D and 2D NMR spectral data, the gross structure of succinilene D (4) was elucidated to be the left part of $\mathbf{1}$ or $\mathbf{2}$, which is the methanolysis product of $\mathbf{1}$ or $\mathbf{2}$ that lacks the succinic acid moiety.

Table 2. NMR data for 3 and 4 in pyridine- $d_{5}$.

\begin{tabular}{|c|c|c|c|c|c|c|}
\hline \multirow{2}{*}{ Position } & \multicolumn{3}{|c|}{3} & \multicolumn{3}{|c|}{4} \\
\hline & $\delta_{H}{ }^{a}$ & Mult ( $J$ in $\mathrm{Hz})$ & $\delta_{C} \mathbf{b}$ & $\delta_{H}{ }^{a}$ & Mult $(J$ in $\mathrm{Hz})$ & $\delta_{C} \mathbf{b}$ \\
\hline 1 & 5.1041 & $\mathrm{dq}(6.33,5.27)$ & $74.2, \mathrm{~d}$ & 3.9666 & $\operatorname{ddq}(6.23,5.00,4.60)$ & $70.8, \mathrm{~d}$ \\
\hline 1-Me & 1.1944 & $\mathrm{~d}(6.33)$ & $17.3, \mathrm{q}$ & 1.3158 & $\mathrm{~d}(6.23)$ & $21.0, \mathrm{q}$ \\
\hline 2 & 2.7403 & $\operatorname{ddq}(9.97,6.86,5.27)$ & $37.2, \mathrm{~d}$ & 2.6988 & $\operatorname{ddq}(9.62,6.85,5.00)$ & $39.6, d$ \\
\hline 2-Me & 1.0069 & $\mathrm{~d}(6.86)$ & $16.6, \mathrm{q}$ & 1.1905 & $\mathrm{~d}(6.85)$ & 17.0, q \\
\hline 3 & 5.5580 & $\mathrm{~d}(9.97)$ & $127.4, \mathrm{~d}$ & 5.8422 & $\mathrm{~d}(9.62)$ & $128.6, \mathrm{~d}$ \\
\hline 4 & - & - & $140.3, \mathrm{~s}$ & - & - & $138.8, \mathrm{~s}$ \\
\hline 4-Me & 1.8616 & $\mathrm{~s}$ & $12.4, \mathrm{q}$ & 1.8782 & $\mathrm{~s}$ & $12.1, \mathrm{q}$ \\
\hline 5 & 4.3767 & $\mathrm{dd}(7.10,6.06)$ & $76.9, \mathrm{~d}$ & 4.4482 & ddd $(7.07,5.51,3.83)$ & $77.2, \mathrm{~d}$ \\
\hline \multirow[t]{2}{*}{6} & 2.6443 & ddd $(-13.79,6.93,6.06)$ & $39.8, \mathrm{t}$ & 2.6890 & ddd $(-13.68,7.07,7.00)$ & $39.9, \mathrm{t}$ \\
\hline & 2.5606 & ddd $(-13.79,7.12,7.10)$ & & 2.6130 & ddd $(-13.68,7.99,5.51)$ & \\
\hline 7 & 5.9652 & ddd $(14.66,7.12,6.93)$ & 132.6, d & 5.9948 & ddd $(14.80,7.99,7.00)$ & $132.1, \mathrm{~d}$ \\
\hline 8 & 6.2708 & $\mathrm{dd}(14.66,10.63)$ & $132.5, \mathrm{~d}$ & 6.2974 & $\mathrm{dd}(14.80,10.62)$ & $132.7, \mathrm{~d}$ \\
\hline 9 & 6.2902 & dd $(15.05,10.63)$ & $132.4, \mathrm{~d}$ & 6.2738 & $\mathrm{dd}(14.86,10.62)$ & $131.8, \mathrm{~d}$ \\
\hline 10 & 6.2414 & $\mathrm{dd}(15.05,10.72)$ & $131.2, \mathrm{~d}$ & 6.3186 & $\mathrm{dd}(14.86,10.55)$ & 132.1, d \\
\hline 11 & 6.3255 & dd $(15.14,10.72)$ & 133.7, d & 6.3706 & dd $(15.21,10.55)$ & 133.0, d \\
\hline 12 & 5.9778 & ddd $(15.14,7.41,7.00)$ & $129.8, \mathrm{~d}$ & 6.2091 & ddd $(15.21,7.38,7.16)$ & $133.2, \mathrm{~d}$ \\
\hline \multirow[t]{2}{*}{13} & 2.7803 & ddd $(-13.49,7.27,7.00)$ & $38.2, \mathrm{t}$ & 2.8870 & ddd $(-14.32,7.38,3.45)$ & $37.6, \mathrm{t}$ \\
\hline & 2.6591 & ddd $(-13.49,7.41,4.88)$ & & 2.7460 & ddd $(-14.32,8.46,7.16)$ & \\
\hline 14 & 4.4922 & $\mathrm{dd}(7.27,4.88)$ & $77.2, \mathrm{~d}$ & 4.0282 & dddd $(8.46,5.85,5.74,3.45)$ & $75.0, \mathrm{~d}$ \\
\hline 15 & - & - & 214.0, s & 3.8872 & dddd $(8.87,5.85,5.90,3.10)$ & $76.2, \mathrm{~d}$ \\
\hline \multirow[t]{2}{*}{16} & 2.7549 & $\mathrm{dq}(-14.89,7.05)$ & $31.7, \mathrm{t}$ & 2.0620 & $\mathrm{ddq}(-13.56,7.35,3.10)$ & $26.5, \mathrm{t}$ \\
\hline & 2.7206 & $\mathrm{dq}(-14.89,7.45)$ & & 1.8533 & $\mathrm{ddq}(-13.56,8.87,7.37)$ & \\
\hline 17 & 1.0890 & dd $(7.45,7.05)$ & $7.8, \mathrm{q}$ & 1.2266 & dd $(7.37,7.35)$ & $10.8, \mathrm{q}$ \\
\hline $1^{\prime}$ & - & - & 172.7, s & & & \\
\hline \multirow[t]{2}{*}{$2^{\prime}$} & 2.8525 & ddd $(-16.88,7.01,6.26)$ & $30.3, \mathrm{t}$ & & & \\
\hline & 2.8525 & ddd $(-16.88,8.79,4.47)$ & & & & \\
\hline \multirow[t]{2}{*}{$3^{\prime}$} & 2.9172 & ddd $(-16.89,8.79,7.01)$ & $30.0, \mathrm{t}$ & & & \\
\hline & 2.9060 & ddd $(-16.89,6.26,4.47)$ & & & & \\
\hline $4^{\prime}$ & - & - & 175.3, s & & & \\
\hline $\mathrm{OH}-1$ & & & & 5.7021 & $\mathrm{~d}(4.60)$ & \\
\hline $\mathrm{OH}-5$ & & & & 6.4159 & $\mathrm{~d}(3.83)$ & \\
\hline $\mathrm{OH}-14$ & & & & 6.1408 & $\mathrm{~d}(5.74)$ & \\
\hline OH-15 & & & & 6.0448 & $\mathrm{~d}(5.90)$ & \\
\hline
\end{tabular}

${ }^{\mathrm{a}} 600 \mathrm{MHz} ;{ }^{\mathrm{b}} 150 \mathrm{MHz}$. The $\delta_{\mathrm{H}}$ (in ppm) and $J$ (in $\mathrm{Hz}$ ) values were determined by HiFSA.

The relative configurations of 1 were established by analyzing the ${ }^{1} \mathrm{H}_{-}{ }^{1} \mathrm{H}$ coupling constants and hetero half-filtered total correlation spectroscopy (HETLOC) NMR data [15]. To determine the relationship between C-1 and C-2, J-based configuration analysis was performed with ${ }^{3} \mathrm{JHH}_{\mathrm{HH}},{ }^{3} \mathrm{JH}_{\mathrm{CH}}$, and ${ }^{2} J_{\mathrm{CH}}$ values and ROESY NMR data [16], selecting the most suitable rotamer between C-1 and C-2 (Figure 2b). The relationship between $\mathrm{H}-1$ and 2-Me was elucidated as anti based on the high ${ }^{3} J_{\mathrm{CH}}$ value $(5.5 \mathrm{~Hz})$. The ${ }^{3} J_{\mathrm{H} 1 \mathrm{H} 2}(5.5 \mathrm{~Hz}),{ }^{3} J_{\mathrm{C} 1-\mathrm{MeH} 2}(2.0 \mathrm{~Hz})$, and ${ }^{3} J_{\mathrm{C} 3 \mathrm{H} 1}(1.7 \mathrm{~Hz})$ values indicated gauche relationships for $\mathrm{H}-1 / \mathrm{H}-2,1-\mathrm{Me} / \mathrm{H}-2$, and $\mathrm{C}-3 / \mathrm{H}-1$. Moreover, the small ${ }^{2} J_{\mathrm{C} 1 \mathrm{H} 2}(3.0 \mathrm{~Hz})$ value and the ROESY NMR signals between the $\mathrm{H}-1 / \mathrm{H}-2, \mathrm{H}-1 / \mathrm{H}-3, \mathrm{H}-2 / 1-\mathrm{Me}$, and 1-Me/2-Me led to select the rotamer depicted in Figure $2 \mathrm{~b}$, thus proposing $1 R^{*}$ and $2 R^{*}$ configuration.

To determine the absolute configurations of the stereogenic centers at C-1, C-2, C-5, C-14, and C-15 in succinilene A (1), the modified Mosher's method was applied [17]. Methanolysis was performed to detach the succinic acid moiety, which enabled derivatization of the hydroxyl group at C-1 with $\alpha$-methoxy trifluoromethyl-phenylacetic acid (MTPA) chloride. After purifying the methanolysis product (5) of succinilene A, the secondary alcohols in $\mathbf{5}$ were derivatized using $R$ - and S-MTPA-Cl. 
Analysis of the ${ }^{1} \mathrm{H}$ and COSY NMR spectroscopic data for these $S$ - and $R$-MTPA esters (8 and 9 ) led to the assignment of the $\Delta \delta_{S-R}$ values, establishing $1 R, 5 S, 14 R$, and $15 R$ configurations (Figure 3a). Based on the established relative configuration, the absolute configuration of $C-2$ was determined to be $2 R$. The relative configurations and absolute configurations of succinilene $\mathrm{B}(2)$ were determined to be $1 R, 2 R, 5 S, 14 R$, and $15 S$ using the same procedure applied for $\mathbf{1}$ (Figure $3 \mathrm{~b}$ ). The relative and absolute configurations of succinilene $C(3)$ were analogously established as $1 R, 2 R, 5 S$, and $15 R$ through application of the modified Mosher's method to the methanolysis product (7) of 3 (Figure 3c). Because the gross structure of succinilene D (4) was identical to the methanolysis products (5 and $\mathbf{6})$ of $\mathbf{1}$ and $\mathbf{2}$, the ${ }^{1} \mathrm{H}$ NMR and CD spectra of $\mathbf{4}$ were compared with those of 5 and $\mathbf{6}$. The ${ }^{1} \mathrm{H}$ NMR data for 6 was identical to those of 4 but was different from the ${ }^{1} \mathrm{H}$ NMR spectrum of 5 , indicating that the relative configuration of $\mathbf{4}$ is identical to that of $\mathbf{6}$. In addition, the CD spectra of $\mathbf{4}$ and $\mathbf{6}$ were identical, thus leading to the assignment of $1 R, 2 R, 5 S, 14 R$, and $15 S$ configurations for 4 (Figure S43).

(a)

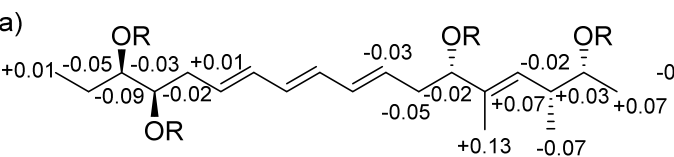

$8: R=S-M T P A$

$9: \mathrm{R}=R-\mathrm{MTPA}$

(c)

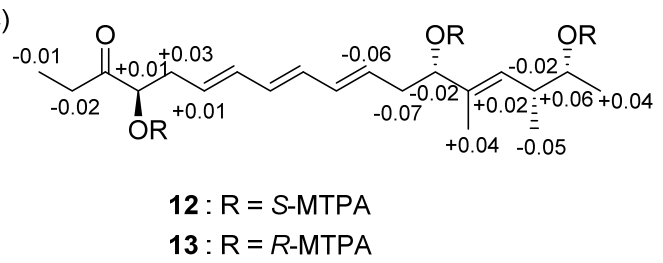

(b)

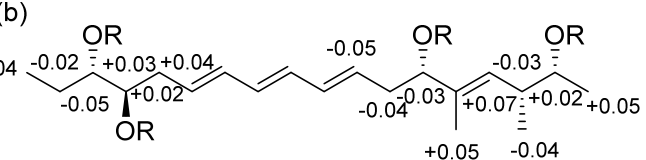

$10: R=S-M T P A$

$11: \mathrm{R}=R-\mathrm{MTPA}$

Figure 3. (a) $\Delta \delta_{S-R}$ values of the MTPA esters (8 and 9) in pyridine- $d_{5} ;$ (b) $\Delta \delta_{S-R}$ values of the MTPA esters (10 and 11) in pyridine- $d_{5} ;$ (c) $\Delta \delta_{S-R}$ values of the MTPA esters (12 and 13) in pyridine- $d_{5}$.

Even though the absolute configurations of the stereogenic centers in 1-4 were completely assigned, the full assignments of the double bond geometries were not straightforward. The geometries of the double bonds of C-7/C-8 and C-11/C-12 in the succinilenes (1-4) were determined as 7E and $11 E$ based on the $\mathrm{H}-7 / \mathrm{H}-8$ and $\mathrm{H}-11 / \mathrm{H}-12$ trans-coupling constant values. However, it was virtually impossible to clarify the double bond geometry of C-9/C-10 in 1-4 because the H-9 and H-10 olefinic protons were greatly overlapped, displaying second-order peaks in the ${ }^{1} \mathrm{H}$ NMR spectra and, thus, hampering the accurate deconvolution of the ${ }^{1} \mathrm{H}-{ }^{1} \mathrm{H}$ coupling constants between $\mathrm{H}-9$ and $\mathrm{H}-10$, even at higher magnetic field $(900 \mathrm{MHz})$.

Therefore, a recently developed computational analysis system, QM-HiFSA [1], was utilized to extract the $\mathrm{H}-9 / \mathrm{H}-10$ coupling constants of the succinilenes using PERCH software. After geometry optimization and dynamic simulation of molecules using the MMS module, the basic ${ }^{1} \mathrm{H}$ NMR parameters were predicted based on the 3D structural information. Then, the obtained initial parameters were optimized by iterative quantum mechanical simulation against experimental spectra. The iteration was repeated until both the simulated and experimental spectra were in excellent agreement with each other, with root mean square (RMS) values below 0.1 (RMS $=0.075$ for 1; RMS $=0.066$ for 2 ; RMS $=0.093$ for 3; RMS $=0.091$ for 4 ) (Figures S44-S47). Thus, the precise ${ }^{1} \mathrm{H}$ NMR parameters were determined with high precision (chemical shifts: $\delta_{\mathrm{H}}, 0.1 \mathrm{ppb}$; coupling constants: $J, 10 \mathrm{mHz}$ ) (Tables 1 and 2) [18]. The $J$ couplings of the highly overlapped olefinic proton signals (H-9 and H-10) of 1-4 were calculated to be $14.03 \mathrm{~Hz}, 14.79 \mathrm{~Hz}, 15.05 \mathrm{~Hz}$, and $14.86 \mathrm{~Hz}$ (cis J couplings ca. $10-12 \mathrm{~Hz}$; trans $J$ couplings ca. $14-18 \mathrm{~Hz}$ ) [18,19], respectively. These results confirmed the $9 E$ geometry of the trans-olefinic protons (H-9 and H-10) in 1-4 (Figure 4). 

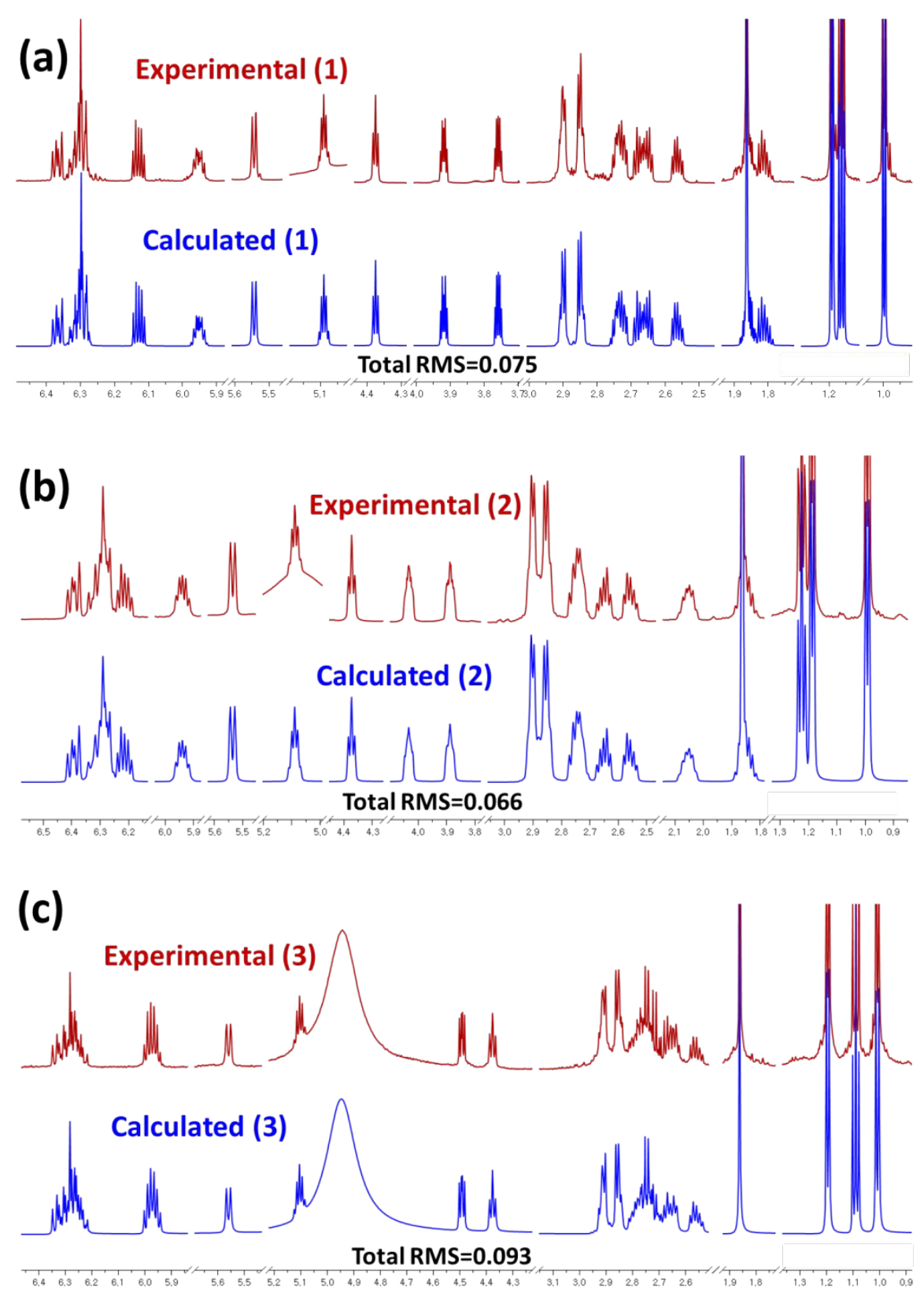

(d)

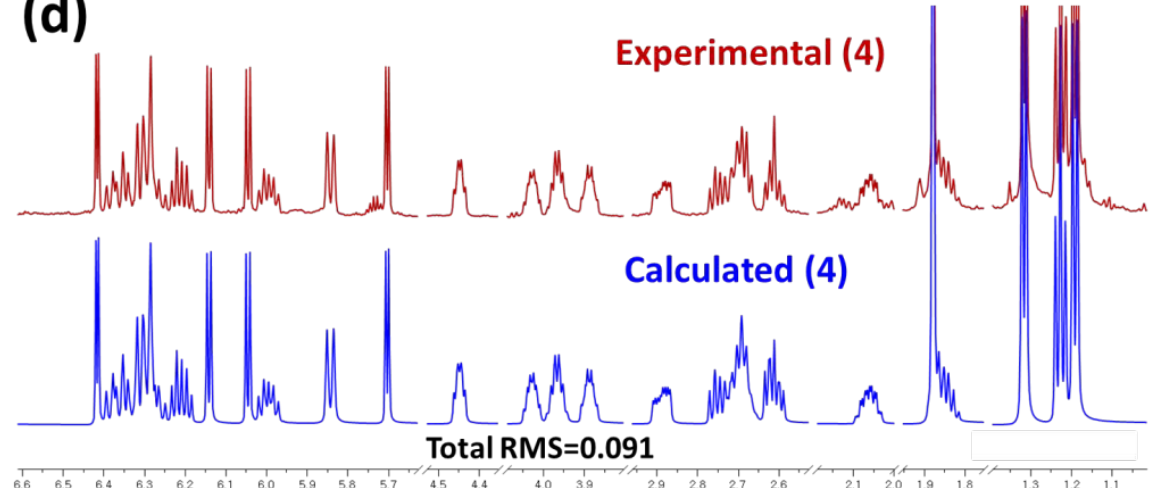

Figure 4. ${ }^{1} \mathrm{H}$ NMR fingerprints of compounds $\mathbf{1}(\mathbf{a})-\mathbf{4}(\mathrm{d})$ generated by HiFSA. Comparison of the observed (red, obtained in pyridine- $d_{5}$ ) and calculated (blue) ${ }^{1} \mathrm{H}$ spectra. 


\subsection{Bioactivities of Succinilenes $A-D$}

The biological activities of the succinilenes (1-4) were primarily evaluated for cytotoxicity against human cancer cells. In this assay, succinilene A showed moderate cytotoxicity against the gastric carcinoma cell line SNU638, with an $\mathrm{IC}_{50}$ value of $12.1 \mu \mathrm{g} / \mathrm{mL}(27.6 \mu \mathrm{M})$, whereas succinilenes B-D did not display significant inhibitory activities against the tested cancer cell lines. As part of the efforts to search for biological activities, a nitrate assay was performed for 1-4. Overproduction of nitric oxide (NO) is highly associated with inflammation, and the pathway that regulates NO production is considered a useful target for anti-inflammatory agents [20]. RAW 264.7 cells were treated with LPS $(1 \mu \mathrm{g} / \mathrm{mL})$, which induces inflammatory responses [21,22]. When the cells were pretreated with various concentrations of the succinilenes $(0,20$, or $40 \mu \mathrm{M}) 30 \mathrm{~min}$ prior to LPS stimulation, NO production was gradually inhibited in a concentration-dependent manner, except for treatment with succinilene D (4). No significant effect on cell viability, as determined by the MTT assay ( $>90 \%$ cell survival), was observed at the tested concentrations, indicating that the inhibition of NO production by the tested compounds was not mediated by a cytotoxic effect. As a result, among the four compounds, succinilene $C$ (3) exhibited the most remarkable inhibitory activity against NO production. By contrast, succinilene $\mathrm{D}$, without succinic acid connected through an ester linkage, resulted in the overproduction of NO (Figure 5).

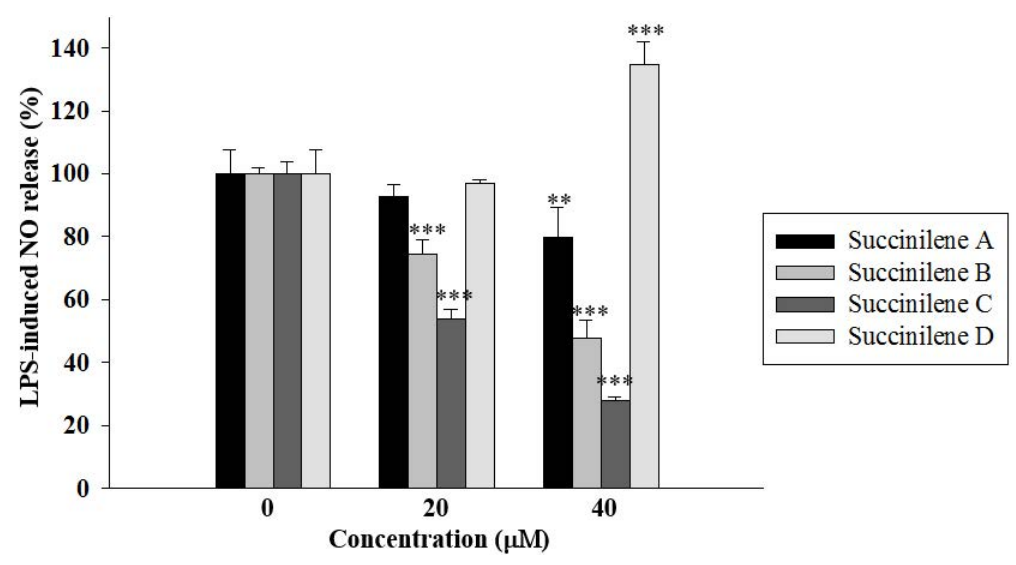

Figure 5. Inhibitory effects of succinilenes A-D (1-4) on LPS-induced NO production. RAW 264.7 cells $\left(3 \times 10^{5}\right.$ cells $\left./ \mathrm{mL}\right)$ were stimulated with LPS $(1 \mu \mathrm{g} / \mathrm{mL})$ in the presence or absence of $1-4$. After $20 \mathrm{~h}$, the cultured media were collected, and the nitrite concentrations were measured using the Griess reaction. ${ }^{* *} p<0.01,{ }^{* * *} p<0.001$ are considered statistically significant compared to the control group.

\section{Experimental Section}

\subsection{General Experimental Procedures}

Optical rotations were measured using a Jasco P-1020 polarimeter (sodium light source, JASCO, Easton, PA, USA) with a 1-cm cell. IR spectra were acquired on a Thermo Nicolet iS10 spectrometer (Thermo, Madison, CT, USA). UV spectra were obtained with a Perkin Elmer Lambda 35 UV-VIS spectrometer (Perkin Elmer, Waltham, MA, USA). Electrospray ionization (ESI) low-resolution LC/MS data were recorded on an Agilent Technologies 6130 quadrupole mass spectrometer coupled to an Agilent Technologies 1200 series HPLC (Agilent Technologies, Santa Clara, CA, USA). High-resolution fast-atom bombardment (HR-FAB) mass spectra were collected with a Jeol JMS-600W high-resolution mass spectrometer (Jeol, Tokyo, Japan) at the National Center for Inter-University Research Facilities (Gwanak-gu, Seoul, Korea). ${ }^{1} \mathrm{H},{ }^{13} \mathrm{C}$, and 2D NMR spectra were obtained on a Bruker Avance $600 \mathrm{MHz}$ spectrometer (Bruker, Billerica, MA, USA) at the NCIRF and a Bruker Avance $900 \mathrm{MHz}$ NMR spectrometer at the Korea Basic Science Institute (Ochang, Chungcheongbuk-do, Korea). 


\subsection{Isolation of Bacteria, Cultivation, and Extraction}

A sediment sample was obtained from the southern area of Jeju Island in a 40-mL sterilized plastic tube. The sample $(1 \mathrm{~g})$ was dried at room temperature (rt) for $3 \mathrm{~h}$ and diluted in $4 \mathrm{~mL}$ of sterilized distilled water. The mixture was spread on actinomycete isolation agar, chitin-based agar, SC medium ( $1 \mathrm{~L}$ of distilled water, $10 \mathrm{~g}$ of starch, $0.3 \mathrm{~g}$ of casein, $2.0 \mathrm{~g}$ of $\mathrm{KNO}_{3}, 2.0 \mathrm{~g}$ of $\mathrm{K}_{2} \mathrm{HPO}_{4}, 0.05 \mathrm{~g}$ of $\mathrm{MgSO}_{4} \cdot 7 \mathrm{H}_{2} \mathrm{O}, 0.02 \mathrm{~g}$ of $\mathrm{CaCO}_{3}, 0.01 \mathrm{~g}$ of $\mathrm{FeSO}_{4} \cdot 7 \mathrm{H}_{2} \mathrm{O}, 16 \mathrm{~g}$ of agar, and $100 \mathrm{mg} / \mathrm{L}$ cycloheximide), and A4 medium (1 L of distilled water, $18 \mathrm{~g}$ of agar, and $100 \mathrm{mg} / \mathrm{L}$ cycloheximide). The strain SAK1 was isolated on SC medium. Based on the analysis of the $16 \mathrm{~S}$ rDNA sequence, SAK1 was clarified to be most closely related to Streptomyces flavogriseus (99\% identity, GenBank accession number: KY484916). For the production of the succinilenes, the strain SAK1 was initially cultivated in $50 \mathrm{~mL}$ of YEME media ( $4 \mathrm{~g}$ of yeast extract, $10 \mathrm{~g}$ of malt extract, and $4 \mathrm{~g}$ of glucose in $1 \mathrm{~L}$ of distilled water) in a $125 \mathrm{~mL}$ Erlenmeyer flask. This seed culture was cultivated for three days on a rotary shaker at $200 \mathrm{rpm}$ at $30^{\circ} \mathrm{C}$. Ten milliliters of the seed culture was inoculated into $1 \mathrm{~L}$ of YEME medium in 2.8-L Fernbach flasks $(12$ ea $\times 1 \mathrm{~L}$, total volume of $12 \mathrm{~L})$. After two days of incubation, the whole culture $(12 \mathrm{~L})$ was extracted twice with $18 \mathrm{~L}$ of ethyl acetate. The ethyl acetate layer was separated by a fractionating funnel and dried over anhydrous sodium sulfate. The ethyl acetate extract was concentrated in vacuo to yield $2 \mathrm{~g}$ of dried material. This procedure was repeated six times ( $72 \mathrm{~L}$ of culture; total amount of extract: $12 \mathrm{~g}$ ) to obtain a sufficient amount of the succinilenes for the structure elucidation and bioassays.

\subsection{Isolation of Succinilenes $A-D$}

The organic extract of the bacterial strain SAK1 culture was adsorbed on Celite, and the extract-Celite mixture was loaded onto a 2-g Sep-Pak $\mathrm{C}_{18}$ cartridge for flash column chromatography. Then, the mixture was fractionated with $20 \mathrm{~mL}$ each of $20 \%, 40 \%, 60 \%, 80 \%$, and $100 \% \mathrm{MeOH}$ in water and 1:1 MeOH/dichloromethane. Succinilenes A-D (1-4) were detected in the $80 \%$ and $100 \%$ $\mathrm{MeOH} /$ water fractions by LC/MS analysis. To obtain pure succinilenes A-D (1-4), the fractions bearing 1-4 were subjected to reversed-phase HPLC (Kromasil $\mathrm{C}_{18}: 250 \times 10 \mathrm{~mm}, 5 \mu \mathrm{m}$ ) with gradient elution (30\% acetonitrile/water to $65 \%$ acetonitrile/water over $40 \mathrm{~min}$; UV detection at $280 \mathrm{~nm}$; flow rate: $2 \mathrm{~mL} / \mathrm{min}$ ). Four major HPLC peaks were collected at retention times of $20 \mathrm{~min}$, $28 \mathrm{~min}, 29 \mathrm{~min}$, and $35 \mathrm{~min}$. These major compounds were further purified under isocratic solvent conditions (65\% methanol/water; UV detection at $280 \mathrm{~nm}$; flow rate: $2 \mathrm{~mL} / \mathrm{min}$ ) on a reversed-phase HPLC column (Kromasil C $18: 250 \times 10 \mathrm{~mm}, 5 \mu \mathrm{m}$ ). Finally, succinilenes A-D (1-4) were isolated as pure compounds at retention times of $33 \mathrm{~min}(12 \mathrm{mg}), 31 \mathrm{~min}(11 \mathrm{mg}), 36 \mathrm{~min}(5 \mathrm{mg})$, and $14 \mathrm{~min}$ ( $2 \mathrm{mg})$, respectively.

\subsubsection{Succinilene A (1)}

$[\alpha]_{\mathrm{D}}-5,\left(c\right.$ 0.05, MeOH); UV (MeOH) $\lambda_{\max }(\log \varepsilon) 270$ (3.92) nm; IR (neat) $v_{\max }$ 3405, 2935, 1647, $1450 \mathrm{~cm}^{-1}$; for ${ }^{1} \mathrm{H}$ and ${ }^{13} \mathrm{C}$ NMR data, see Table 1; HRFABMS $\mathrm{m} / z$ 437.2550 [M - H] ${ }^{-}$(calcd. for $\mathrm{C}_{24} \mathrm{H}_{37} \mathrm{O}_{7}$ 437.2539).

\subsubsection{Succinilene B (2)}

$[\alpha]_{\mathrm{D}}-8,(c 0.05, \mathrm{MeOH}) ; \mathrm{UV}(\mathrm{MeOH}) \lambda_{\max }(\log \varepsilon) 270$ (3.89) nm; IR (neat) $v_{\max } 3410,2930,1652$, $1452 \mathrm{~cm}^{-1}$; for ${ }^{1} \mathrm{H}$ and ${ }^{13} \mathrm{C}$ NMR data, see Table 1; HRFABMS $\mathrm{m} / z$ 437.2550 $[\mathrm{M}-\mathrm{H}]^{-}$(calcd. for $\left.\mathrm{C}_{24} \mathrm{H}_{37} \mathrm{O}_{7} 437.2539\right)$.

\subsubsection{Succinilene C (3)}

$[\alpha]_{\mathrm{D}}-3,\left(c\right.$ 0.05, MeOH); UV (MeOH) $\lambda_{\max }(\log \varepsilon) 270$ (3.94) nm; IR (neat) $v_{\max }$ 3392, 2944, 1647, $1452 \mathrm{~cm}^{-1}$; for ${ }^{1} \mathrm{H}$ and ${ }^{13} \mathrm{C}$ NMR data, see Table 2; HRFABMS $m / z 437.2545[\mathrm{M}+\mathrm{H}]^{+}$(calcd. for $\mathrm{C}_{24} \mathrm{H}_{37} \mathrm{O}_{7} 437.2562$ ). 


\subsubsection{Succinilene D (4)}

$[\alpha]_{\mathrm{D}}-6,\left(c\right.$ 0.05, MeOH); UV (MeOH) $\lambda_{\max }(\log \varepsilon) 270$ (3.85) nm; IR (neat) $v_{\max } 3407,2924,1650$, $1454 \mathrm{~cm}^{-1}$; for ${ }^{1} \mathrm{H}$ and ${ }^{13} \mathrm{C}$ NMR data, see Table 2; HRFABMS $\mathrm{m} / z 361.2347[\mathrm{M}+\mathrm{Na}]^{+}$(calcd. for $\mathrm{C}_{20} \mathrm{H}_{34} \mathrm{O}_{4} \mathrm{Na}$ 361.2355).

\subsection{Methanolysis of Succinilenes A-C}

Succinilene A (1) (5 mg) was dissolved in $2 \mathrm{~mL}$ of $\mathrm{MeOH}$, and $28 \mathrm{mg}$ of $\mathrm{NaOMe}$ was added to the vial to prepare a $0.5 \mathrm{M} \mathrm{NaOMe}$ solution. The mixture was stirred at room temperature for $5 \mathrm{~h}$. The reaction was quenched by the addition of $1 \mathrm{~N} \mathrm{HCl}$. The methanolysis product was extracted by water-ethyl acetate partitioning after evaporating the $\mathrm{MeOH}$ in vacuo. After removing the solvent, the methanolysis product (5) was purified by HPLC using gradient elution conditions $(10 \%-100 \%$ acetonitrile/water over $40 \mathrm{~min}$; UV detection at $280 \mathrm{~nm}$; flow rate: $2 \mathrm{~mL} / \mathrm{min}$ ) and a reversed-phase HPLC column (Kromasil $C_{18}: 250 \times 10 \mathrm{~mm}, 5 \mu \mathrm{m}$ ). The methanolysis product (5) eluted at a retention time of $25 \mathrm{~min}$. The structure of 5 was confirmed by analysis of its ${ }^{1} \mathrm{H}$ and 2D NMR spectral data (Figures S22-S24) and ESI mass spectra ([M + H] $]^{+} m / z$ at 339; molecular formula, $\left.\mathrm{C}_{20} \mathrm{H}_{35} \mathrm{O}_{4}\right)$. The same procedures were repeated for succinilenes $\mathrm{B}$ and $\mathrm{C}$ ( 2 and 3 ). The structures of the methanolysis products of 2 and 3 ( 6 and 7) were also assigned based on the analysis of ${ }^{1} \mathrm{H}$ and 2D NMR spectral data (Figures S25-S30) and ESI mass spectra (for 6, $[\mathrm{M}+\mathrm{H}]^{+} \mathrm{m} / \mathrm{z}$ at 339 and molecular formula of $\mathrm{C}_{20} \mathrm{H}_{33} \mathrm{O}_{4}$; for 7 , $[\mathrm{M}+\mathrm{H}]^{+} m / z$ at 337 and molecular formula of $\mathrm{C}_{20} \mathrm{H}_{33} \mathrm{O}_{4}$ ).

\subsection{MTPA Esterification of Succinilenes A-C}

The methanolysis products of succinilenes A-C (5-7) were prepared individually in 40-mL vials (two 1-mg samples for each compound) and dried completely under high vacuum overnight. After adding catalytic amounts of crystalline $N, N$-dimethylaminopyridine (DMAP) to each reaction vial, freshly distilled anhydrous pyridine $(1 \mathrm{~mL})$ was added under argon gas. The reaction mixtures were stirred at room temperature for $5 \mathrm{~min}$. After $5 \mathrm{~min}, R$ - and $S$ - $\alpha$-methoxy trifluoromethyl-phenylacetic acid (MTPA) chloride $(20 \mu \mathrm{L})$ were added, respectively. The reactions were carried out for $3 \mathrm{~h}$ at room temperature with stirring. The reactions were quenched by adding $50 \mu \mathrm{L}$ of $\mathrm{MeOH}$. The reaction products were purified by HPLC using gradient elution conditions of $40 \%$ to $100 \%$ aqueous acetonitrile over $20 \mathrm{~min}$ with a reversed-phase $\mathrm{C}_{18}$ column (Kromasil $\mathrm{C}_{18}$ : $250 \times 10 \mathrm{~mm}, 5 \mu \mathrm{m}$; flow rate: $2 \mathrm{~mL} / \mathrm{min}$; UV detection at $280 \mathrm{~nm})$. The tetra-S- and -R-MTPA esters (8 and $\mathbf{9}$ ) of 5 eluted at 34.3 and $35.2 \mathrm{~min}$, respectively. The tetra-S- and -R-MTPA esters (10 and 11) of $\mathbf{6}$ eluted at 33.5 and $34.7 \mathrm{~min}$. The tetra-S- and -R-MTPA esters (12 and 13) of 7 were isolated at 36.1 and $37.3 \mathrm{~min}$. The $\Delta \delta_{S-R}$ values around the stereogenic centers of the MTPA esters were assigned based on the analysis of ${ }^{1} \mathrm{H}$ and ${ }^{1} \mathrm{H}-{ }^{1} \mathrm{H}$ COSY NMR spectra.

\subsubsection{Tetra S-MTPA Ester (8) of Methanolysis Product (5) of Succinilene A (1)}

${ }^{1} \mathrm{H}$ NMR $\left(600 \mathrm{MHz}\right.$, pyridine- $\left.d_{5}\right) \delta$ 7.83-7.81 $(\mathrm{m}, 4 \mathrm{H}), 7.78-7.75(\mathrm{~m}, 4 \mathrm{H}), 7.48-7.45(\mathrm{~m}, 12 \mathrm{H}), 6.32-6.17$ $(\mathrm{m}, 4 \mathrm{H}), 5.73(\mathrm{~m}, 1 \mathrm{H}), 5.67-5.60(\mathrm{~m}, 4 \mathrm{H}), 5.41(\mathrm{~d}, J=6.5,1 \mathrm{H}), 5.26(\mathrm{~m}, 1 \mathrm{H}), 3.67(\mathrm{~s}, 3 \mathrm{H}), 3.62(\mathrm{~s}, 9 \mathrm{H}), 2.75$ $(\mathrm{m}, 1 \mathrm{H}), 2.63-2.54(\mathrm{~m}, 2 \mathrm{H}), 2.51-2.46(\mathrm{~m}, 2 \mathrm{H}), 1.76(\mathrm{~s}, 3 \mathrm{H}), 1.72(\mathrm{~m}, 1 \mathrm{H}), 1.58(\mathrm{~m}, 1 \mathrm{H}), 1.32(\mathrm{~d}, J=6.5,3 \mathrm{H})$, $0.93(\mathrm{~d}, J=6.5,3 \mathrm{H}), 0.88(\mathrm{t}, J=6.5,3 \mathrm{H})$. The molecular formula of 8 was confirmed as $\mathrm{C}_{60} \mathrm{H}_{62} \mathrm{~F}_{12} \mathrm{O}_{12} \mathrm{Na}$ $\left([\mathrm{M}+\mathrm{Na}]^{+}\right.$at $m / z$ 1227).

\subsubsection{Tetra-R-MTPA Ester (9) of Methanolysis Product (5) of Succinilene A (1)}

${ }^{1} \mathrm{H}$ NMR $\left(600 \mathrm{MHz}\right.$, pyridine- $\left.d_{5}\right) \delta$ 7.82-7.81 $(\mathrm{m}, 4 \mathrm{H}), 7.79-7.76(\mathrm{~m}, 4 \mathrm{H}), 7.49-7.44(\mathrm{~m}, 12 \mathrm{H}), 6.30-6.22$ $(\mathrm{m}, 4 \mathrm{H}), 5.75-5.71(\mathrm{~m}, 2 \mathrm{H}), 5.67(\mathrm{t}, J=7.0,1 \mathrm{H}), 5.63(\mathrm{~d}, J=7.0,1 \mathrm{H}), 5.56(\mathrm{~d}, J=9.5,1 \mathrm{H}), 5.50$ $(\mathrm{t}, J=7.0,1 \mathrm{H}), 5.25(\mathrm{~m}, 1 \mathrm{H}), 3.65(\mathrm{~s}, 3 \mathrm{H}), 3.63(\mathrm{~s}, 3 \mathrm{H}), 3.62(\mathrm{~s}, 3 \mathrm{H}), 3.59(\mathrm{~s}, 3 \mathrm{H}), 2.77(\mathrm{~m}, 1 \mathrm{H}), 2.68$ $(\mathrm{m}, 1 \mathrm{H}) 2.64-2.61(\mathrm{~m}, 2 \mathrm{H}), 2.55(\mathrm{~m}, 1 \mathrm{H}), 1.80-1.74(\mathrm{~m}, 2 \mathrm{H}), 1.63(\mathrm{~s}, 3 \mathrm{H}), 1.25(\mathrm{~d}, J=6.5,3 \mathrm{H}), 1.00$ 
$(\mathrm{d}, J=6.5,3 \mathrm{H}), 0.86(\mathrm{t}, J=6.5,3 \mathrm{H})$. The molecular formula of 9 was confirmed as $\mathrm{C}_{60} \mathrm{H}_{62} \mathrm{~F}_{12} \mathrm{O}_{12} \mathrm{Na}$ $\left([\mathrm{M}+\mathrm{Na}]^{+}\right.$at $m / z$ 1227).

3.5.3. Tetra-S-MTPA Ester (10) of Methanolysis Product (6) of Succinilene B (2)

${ }^{1} \mathrm{H}$ NMR (600 MHz, pyridine- $\left.d_{5}\right) \delta 7.81-7.77(\mathrm{~m}, 8 \mathrm{H}), 7.48-7.45(\mathrm{~m}, 12 \mathrm{H}), 6.32-6.25(\mathrm{~m}, 3 \mathrm{H}), 6.19$ $(\mathrm{dd}, J=14.5,10.5,1 \mathrm{H}), 5.80-5.75(\mathrm{br}, 3 \mathrm{H}), 5.65(\mathrm{~m}, 1 \mathrm{H}), 5.64(\mathrm{~m}, 1 \mathrm{H}), 5.61(\mathrm{~m}, 1 \mathrm{H}), 5.58(\mathrm{br}, 1 \mathrm{H}), 3.67$ $(\mathrm{s}, 6 \mathrm{H}), 3.61(\mathrm{~s}, 6 \mathrm{H}), 2.74(\mathrm{br}, 1 \mathrm{H}), 2.68-2.66(\mathrm{~m}, 2 \mathrm{H}), 2.58(\mathrm{~m}, 1 \mathrm{H}), 2.49(\mathrm{~m}, 1 \mathrm{H}), 1.73(\mathrm{~m}, 3 \mathrm{H}), 1.67-1.62$ $(\mathrm{m}, 2 \mathrm{H}), 0.94(\mathrm{~d}, J=6.5,3 \mathrm{H}), 0.89(\mathrm{~d}, J=6.5,3 \mathrm{H}), 0.86(\mathrm{t}, J=7.5,3 \mathrm{H})$. The molecular formula of 10 was confirmed as $\mathrm{C}_{60} \mathrm{H}_{62} \mathrm{~F}_{12} \mathrm{O}_{12} \mathrm{Na}\left([\mathrm{M}+\mathrm{Na}]^{+}\right.$at $m / z$ 1227).

3.5.4. Tetra-R-MTPA Ester (11) of Methanolysis Product (6) of Succinilene B (2)

${ }^{1} \mathrm{H}$ NMR $\left(600 \mathrm{MHz}\right.$, pyridine- $\left.d_{5}\right) \delta 7.75-7.73(\mathrm{~m}, 8 \mathrm{H}), 7.46-7.44(\mathrm{~m}, 12 \mathrm{H}), 6.30-6.29(\mathrm{~m}, 2 \mathrm{H}), 6.24(\mathrm{~m}, 1 \mathrm{H})$, $6.17(\mathrm{~m}, 1 \mathrm{H}), 5.76-5.72(\mathrm{br}, 3 \mathrm{H}), 5.67(\mathrm{~m}, 1 \mathrm{H}), 5.63(\mathrm{~m}, 1 \mathrm{H}), 5.58(\mathrm{br}, 1 \mathrm{H}), 5.56(\mathrm{~d}, J=9.5,1 \mathrm{H}), 3.66(\mathrm{~s}, 3 \mathrm{H})$, $3.63(\mathrm{~s}, 6 \mathrm{H}), 3.58(\mathrm{~s}, 3 \mathrm{H}), 2.77(\mathrm{br}, 1 \mathrm{H}), 2.67(\mathrm{~m}, 1 \mathrm{H}) 2.56-2.54(\mathrm{~m}, 2 \mathrm{H}), 2.45(\mathrm{~m}, 1 \mathrm{H}), 1.76(\mathrm{~m}, 2 \mathrm{H}), 1.68$ $(\mathrm{s}, 3 \mathrm{H}), 0.98(\mathrm{~d}, J=6.5,3 \mathrm{H}), 0.90(\mathrm{t}, J=7.5,3 \mathrm{H}), 0.84(\mathrm{~d}, J=6.5,3 \mathrm{H})$. The molecular formula of 11 was confirmed as $\mathrm{C}_{60} \mathrm{H}_{62} \mathrm{~F}_{12} \mathrm{O}_{12} \mathrm{Na}\left([\mathrm{M}+\mathrm{Na}]^{+}\right.$at $m / z$ 1227).

3.5.5. Tetra-S-MTPA Ester (12) of Methanolysis Product (7) of Succinilene C (3)

${ }^{1} \mathrm{H}$ NMR $\left(600 \mathrm{MHz}\right.$, pyridine- $\left.d_{5}\right) \delta$ 7.81-7.78 $(\mathrm{m}, 6 \mathrm{H}), 7.50-7.47(\mathrm{~m}, 9 \mathrm{H}), 6.25-6.15(\mathrm{~m}, 3 \mathrm{H}), 6.02$ $(\mathrm{dd}, J=15.0,9.5,1 \mathrm{H}), 5.73(\mathrm{~m}, 1 \mathrm{H}), 5.67-5.62(\mathrm{~m}, 2 \mathrm{H}), 5.57(\mathrm{~m}, 1 \mathrm{H}), 5.55(\mathrm{~d}, J=9.5,1 \mathrm{H}), 5.28(\mathrm{~m}, 1 \mathrm{H})$, $3.67(\mathrm{~s}, 3 \mathrm{H}), 3.65(\mathrm{~s}, 3 \mathrm{H}), 3.63(\mathrm{~s}, 3 \mathrm{H}), 2.92(\mathrm{~m}, 1 \mathrm{H}), 2.82-2.73(\mathrm{~m}, 2 \mathrm{H}), 2.69(\mathrm{~m}, 1 \mathrm{H}), 2.58-2.50(\mathrm{~m}, 3 \mathrm{H})$, $1.69(\mathrm{~s}, 3 \mathrm{H}), 1.13(\mathrm{~d}, J=6.5,3 \mathrm{H}), 1.05(\mathrm{t}, J=7.5,3 \mathrm{H}), 0.89(\mathrm{~d}, J=6.5,3 \mathrm{H})$. The molecular formula of 12 was confirmed as $\mathrm{C}_{50} \mathrm{H}_{53} \mathrm{~F}_{9} \mathrm{O}_{10} \mathrm{Na}\left([\mathrm{M}+\mathrm{Na}]^{+}\right.$at $m / z$ 1007).

3.5.6. Tetra-R-MTPA Ester (13) of Methanolysis Product (7) of Succinilene C (3)

${ }^{1} \mathrm{H}$ NMR $\left(600 \mathrm{MHz}\right.$, pyridine- $\left.d_{5}\right) \delta 7.82-7.80(\mathrm{~m}, 6 \mathrm{H}), 7.51-7.48(\mathrm{~m}, 9 \mathrm{H}), 6.23-6.15(\mathrm{~m}, 4 \mathrm{H}), 5.74(\mathrm{~m}, 1 \mathrm{H})$, $5.66-5.60(\mathrm{~m}, 2 \mathrm{H}), 5.58(\mathrm{t}, J=6.5,1 \mathrm{H}), 5.42(\mathrm{~m}, 1 \mathrm{H}), 5.26(\mathrm{~m}, 1 \mathrm{H}), 3.69(\mathrm{~s}, 3 \mathrm{H}), 3.65(\mathrm{~s}, 3 \mathrm{H}), 3.63(\mathrm{~s}, 3 \mathrm{H})$, $2.91(\mathrm{~m}, 1 \mathrm{H}), 2.84-2.75(\mathrm{~m}, 2 \mathrm{H}), 2.62(\mathrm{~m}, 1 \mathrm{H}), 2.57-2.51(\mathrm{~m}, 3 \mathrm{H}), 1.65(\mathrm{~s}, 3 \mathrm{H}), 1.18(\mathrm{~d}, J=6.5,3 \mathrm{H}), 1.06$ $(\mathrm{t}, J=7.5,3 \mathrm{H}), 0.85(\mathrm{~d}, J=6.5,3 \mathrm{H})$. The molecular formula of $\mathbf{1 3}$ was confirmed as $\mathrm{C}_{50} \mathrm{H}_{53} \mathrm{~F}_{9} \mathrm{O}_{10} \mathrm{Na}$ $\left([\mathrm{M}+\mathrm{Na}]^{+}\right.$at $m / z$ 1007).

\subsection{Evaluation of Antiproliferative Activity}

The effects of succinilenes A-D (1-4) on cell proliferation were evaluated by the sulforhodamine B (SRB) cellular protein-staining assay, with slight modifications. Briefly, A549 (lung cancer), SNU638 (gastric cancer), and HCT116 (colon cancer) cells $\left(1 \times 10^{4}\right.$ cells in $190 \mu \mathrm{L}$ of complete RPMI 1640 medium) were seeded in a 96-well plate with various concentrations of $\mathbf{1 - 4}$ and incubated at $37^{\circ} \mathrm{C}$ in a humidified atmosphere containing $5 \% \mathrm{CO}_{2}$. After $72 \mathrm{~h}$ of treatment with succinilenes A-D (1-4), the cells were fixed with a $10 \%$ TCA solution for $1 \mathrm{~h}$, and cellular proteins were stained with $0.4 \%$ SRB in a $1 \%$ acetic acid solution. The stained cells were dissolved in $10 \mathrm{mM}$ Tris buffer ( $\mathrm{pH} 10.0)$. The effects of 1-4 on cell viability were calculated as percentages relative to the solvent-treated control. The $\mathrm{IC}_{50}$ values were calculated using nonlinear regression analysis (percent survival versus concentration).

\subsection{Evaluation of $i-N O S$ Assay}

\subsubsection{Materials}

Dulbecco's modified Eagle's medium (DMEM), fetal bovine serum (FBS), sodium pyruvate, L-glutamine, antibiotics-antimycotics solution, and trypsin-EDTA were purchased from Invitrogen Co. (Grand Island, NY, USA). Lipopolysaccharide (LPS, Escherichia coli 0111:B4), 3-(4,5-dimethylthiazol2-yl)-2,5-diphenyltetrazolium bromide (MTT), and other chemicals were purchased from Sigma (St. Louis, MO, USA). 


\subsubsection{Cell Culture}

Mouse macrophage RAW 264.7 cells, provided from the American Type Culture Collection (ATCC, Rockville, MD, USA), were cultured in DMEM supplemented with $10 \%$ heat-inactivated fetal bovine serum (FBS) and antibiotics-antimycotics (PSF; 100 units $/ \mathrm{mL}$ penicillin G sodium, $100 \mu \mathrm{g} / \mathrm{mL}$ streptomycin, and $250 \mathrm{ng} / \mathrm{mL}$ amphotericin B). Cells was incubated in humidified atmosphere containing $5 \% \mathrm{CO}_{2}$ at $37^{\circ} \mathrm{C}$.

\subsubsection{Nitrite Assay}

To evaluate the inhibitory activity of succinilenes A-D (1-4) on LPS-induced NO production, RAW 264.7 cells were cultured in 10\% FBS-DMEM without phenol red, plated in 24-well plates $\left(3 \times 10^{5}\right.$ cells $\left./ \mathrm{mL}\right)$, and incubated for $24 \mathrm{~h}$. Cells were washed with PBS, fresh medium was added, and the cells were incubated with $1 \mu \mathrm{g} / \mathrm{mL}$ LPS in the presence or absence of test compounds. After additional $20 \mathrm{~h}$ of incubation, the media were collected and analyzed for nitrite accumulation as an indicator of NO production by the Griess reaction. Briefly, $180 \mu \mathrm{L}$ of Griess reagents ( $0.1 \% \mathrm{~N}$-(1-naphthyl)ethylenediamine dihydrochloride in $\mathrm{H}_{2} \mathrm{O}$ and $1 \%$ sulfanilamide in $5 \% \mathrm{H}_{3} \mathrm{PO}_{4}$ ) was added to $100 \mu \mathrm{L}$ of each supernatant from LPS or sample-treated cells in 96-well plates. The absorbance was measured at $540 \mathrm{~nm}$, and nitrite concentration was determined by comparison with a sodium nitrite standard curve. Percent inhibition was expressed as [1 - (NO level of test samples/NO levels of vehicle-treated control)] $\times 100$.

\subsubsection{Statistical Analysis}

Data are presented as the means \pm SD for the indicated number of independently performed experiments. Statistical significance $(p<0.01)$ was assessed by a one-way analysis of variation (ANOVA) coupled with the Dunnett's $t$-test.

\subsection{Computer-Aided NMR Spectral Analysis}

The PERCH NMR software package (ver. 2013.1, PERCH Solutions Ltd., Kuopio, Finland) was used for HiFSA, as previously described [2,23-25]. The final optimized NMR parameters of compounds 1-4 are provided as PERCH parameter text files ( ${ }^{*}$.pms) (Figures S44-S47).

\section{Conclusions}

Succinilenes A-D (1-4) were discovered from a marine-derived Streptomyces sp. through chemical profiling of a marine actinomycete strain collection. Spectroscopic analysis of 1-4 was used to assign their structures as new polyene polyol compounds, each bearing a conjugated triene moiety. These compounds were biologically evaluated for inhibitory effects on LPS-induced NO production, indicating their anti-inflammatory significance. Succinilenes A-C, commonly incorporating a succinic acid moiety, displayed significant inhibitory effects on $\mathrm{NO}$ production whereas succinilene $\mathrm{D}$ without succinic acid did not inhibit NO production, thus proposing that the succinic moiety is important for the inhibitory effects on LPS-induced NO production. Microbial metabolites having succinic acid are not common, but a few microbial polyketide compounds are known to bear succinic acid in their structures, such as macrolactin T from the marine bacterium Bacillus marinus [26], reveromycin A from Streptomyces sp. [27], and macrocyclic lactone A26771B from the fungus Penicillium turbatum [28]. These succinic acid-bearing compounds have not been tested for the inhibitory activities on LPS-induced NO production.

Since the chemical shifts of the olefinic protons belonging to the triene moieties and, thus, coupling with each other, are close enough to generate second-order peaks, the triene geometries of the succinilenes could not be determined using conventional methods. Our application of the spin simulation of QM-HiFSA enabled us to calculate the ${ }^{1} \mathrm{H}-{ }^{1} \mathrm{H}$ coupling constants of these double bond protons and successfully determine the triene geometries. These results suggest that the QM-HiFSA 
technique is a useful tool for the detailed structural elucidation of complicated natural products displaying highly overlapped ${ }^{1} \mathrm{H}$ NMR spectra.

Supplementary Materials: The following are available online at www.mdpi.com/1660-3397/15/2/38/s1. Figures S1-S6: ${ }^{1} \mathrm{H},{ }^{13} \mathrm{C}, \mathrm{COSY}, \mathrm{HSQC}, \mathrm{HMBC}$, and HETLOC NMR data of $\mathbf{1}$ in pyridine- $d_{5}$, Figures S7-S11: ${ }^{1} \mathrm{H},{ }^{13} \mathrm{C}, \mathrm{COSY}, \mathrm{HSQC}$, and HMBC NMR data of 2 in pyridine- $d_{5}$, Figures S12-S16: ${ }^{1} \mathrm{H},{ }^{13} \mathrm{C}$, COSY, HSQC, and HMBC NMR data of 3 in pyridine- $d_{5}$, Figures S17-S21: ${ }^{1} \mathrm{H},{ }^{13} \mathrm{C}, \mathrm{COSY}, \mathrm{HSQC}$, and HMBC NMR data of 4 in pyridine- $d_{5}$, Figures S22-S24: ${ }^{1} \mathrm{H}, \mathrm{COSY}$, and HSQC NMR data of methanolysis product of succinilene A (5) in pyridine- $d_{5}$, Figures S25-S27: ${ }^{1} \mathrm{H},{ }^{13} \mathrm{C}, \mathrm{COSY}$, and HSQC NMR data of methanolysis product of succinilene B (6) in pyridine- $d_{5}$, Figures S28-S30: ${ }^{1} \mathrm{H},{ }^{13} \mathrm{C}, \mathrm{COSY}$, and HSQC NMR data of methanolysis product of succinilene $\mathrm{C}(7)$ in pyridine- $d_{5}$, Figures S31 and S32: ${ }^{1} \mathrm{H}$ and COSY NMR data of $S$-MTPA ester (8) of 5 in pyridine- $d_{5}$, Figures S33 and S34: ${ }^{1} \mathrm{H}$ and COSY NMR data of $R$-MTPA ester (9) of 5 in pyridine- $d_{5}$, Figures S35 and S36: ${ }^{1} \mathrm{H}$ and COSY NMR data of S-MTPA ester (10) of 6 in pyridine- $d_{5}$, Figures S37 and S38: ${ }^{1} \mathrm{H}$ and COSY NMR data of $R$-MTPA ester (11) of 6 in pyridine- $d_{5}$, Figures S39 and S40: ${ }^{1} \mathrm{H}$ and COSY NMR data of S-MTPA ester (12) of 7 in pyridine- $d_{5}$, Figures S41 and S42: ${ }^{1} \mathrm{H}$ and COSY NMR data of $R$-MTPA ester (13) of 7 in pyridine- $d_{5}$, Figure S43: ECD spectra of 5, 6, and succinilene D (4), Figures S44-S47: The ${ }^{1} \mathrm{H}$ NMR fingerprint of 1-4 (PERCH .pms file format).

Acknowledgments: This work was supported by a National Research Foundation of Korea (NRF) grant funded by the Korean government (Ministry of ICT and Future Planning, No. 2014R1A2A1A11053477). This work was also funded by the 2016 Yeungnam University Research Grant. We would like to thank the Basic Science Research Institute at Ochang, Korea, for performing the high-field NMR experiments. The authors also thank Guido F. Pauli (UIC, US) and Matthias Niemitz (PERCH Solutions Ltd., Finland) for supportive discussions related to HiFSA.

Author Contributions: Munhyung Bae, Sang Kook Lee, Jongheon Shin, Joo-Won Nam and Dong-Chan Oh conceived and designed the experiments. Munhyung Bae isolated and cultivated the bacterial strain, isolated the compounds, performed the chemical experiments, and analyzed the spectroscopic data. Joo-Won Nam analyzed NMR data using QM-HiFSA. So Hyun Park performed the biological tests. Yun Kwon contributed to the preparation of materials. Munhyung Bae, So Hyun Park, Sang Kook Lee, Jongheon Shin, Joo-Won Nam and Dong-Chan Oh wrote the paper.

Conflicts of Interest: The authors declare no conflict of interest.

\section{References}

1. Napolitano, J.G.; Gödecke, T.; Rodriguez-Brasco, M.F.; Jaki, B.U.; Chen, S.-N.; Lankin, D.C.; Pauli, G.F. The tandem of full spin analysis and qHNMR for the quality control of botanicals exemplified with Ginkgo biloba. J. Nat. Prod. 2012, 75, 238-248. [CrossRef] [PubMed]

2. Napolitano, J.G.; Lankin, D.C.; Chen, S.-N.; Pauli, G.F. Complete ${ }^{1}$ H NMR spectral analysis of ten chemical markers of Ginkgo biloba. Magn. Reson. Chem. 2012, 50, 569-575. [CrossRef] [PubMed]

3. Niemitz, M.; Laatikainen, R.; Chen, S.-N.; Kleps, R.; Kozikowski, A.P.; Pauli, G.F. Complete ${ }^{1} \mathrm{H}$ NMR spectral fingerprint of huperzine A. Magn. Reson. Chem. 2007, 45, 878-882. [CrossRef] [PubMed]

4. Fenical, W.; Jensen, P.R. Developing a new resource for drug discovery: marine actinomycete bacteria. Nat. Chem. Biol. 2006, 2, 666-673. [CrossRef] [PubMed]

5. Kim, S.-H.; Shin, Y.; Lee, S.-H.; Oh, K.-B.; Lee, S.K.; Shin, J.; Oh, D.-C. Salternamides A-D from a halophilic Streptomyces sp. actinobacterium. J. Nat. Prod. 2015, 78, 836-843. [CrossRef] [PubMed]

6. Kim, S.-H.; Shin, Y.; Lee, S.K.; Shin, J.; Oh, D.-C. Salternamide E from a saltern-derived marine actinomycete Streptomyces sp. Nat. Prod. Sci. 2015, 21, 273-277. [CrossRef]

7. Kim, S.-H.; Ha, T.-K.-Q.; Oh, W.K.; Shin, J.; Oh, D.-C. Antiviral indolosesquiterpenoid xiamycins C-E from a halophilic Streptomyces sp. actinomycete. J. Nat. Prod. 2016, 79, 51-58. [CrossRef] [PubMed]

8. Bae, M.; Kim, H.; Moon, K.; Nam, S.-J.; Shin, J.; Oh, K.-B.; Oh, D.-C. Mohangamides A and B, new dilactone-tethered pseudo-dimeric peptides inhibiting Candida albicans isocitrate lyase. Org. Lett. 2015, 17, 712-715. [CrossRef] [PubMed]

9. Bae, M.; Chung, B.; Oh, K.-B.; Shin, J.; Oh, D.-C. Hormaomycins B and C: New antibiotic cyclic depsipeptides from a marine mudflat-derived Streptomyces sp. Mar. Drugs 2015, 13, 5187-5200. [CrossRef] [PubMed]

10. Shin, B.; Ahn, S.; Noh, M.; Shin, J.; Oh, D.-C. Suncheonosides A-D, benzothioate glycosides from a marine-derived Streptomyces sp. J. Nat. Prod. 2015, 78, 1390-1396. [CrossRef] [PubMed]

11. Um, S.; Choi, T.J.; Lee, S.-H.; Kim, B.Y.; Kim, S.-H.; Lee, S.K.; Oh, K.-B.; Shin, J.; Oh, D.-C. Ohmyungsamycins A and B: cytotoxic and antimicrobial cyclic peptides produced by Streptomyces sp. from a volcanic island. J. Org. Chem. 2013, 78, 12321-12329. [CrossRef] [PubMed] 
12. Um, S.; Kim, Y.-J.; Kwon, H.; Wen, H.; Kim, S.-H.; Kwon, H.C.; Park, S.; Shin, J.; Oh, D.-C. Sungsanpin, a lasso peptide from a deep-sea streptomycete. J. Nat. Prod. 2013, 76, 873-879. [CrossRef] [PubMed]

13. Park, S.-H.; Moon, K.; Bang, H.-S.; Kim, S.-H.; Kim, D.-G.; Oh, K.-B.; Shin, J.; Oh, D.-C. Tripartilactam, a cyclobutane-bearing tricyclic lactam from a Streptomyces sp. in a dung beetle's brood ball. Org. Lett. 2012, 14, 1258-1261. [CrossRef] [PubMed]

14. Oh, D.-C.; Poulsen, M.; Currie, C.R.; Clardy, J. Sceliphrolactam, a polyene macrocyclic lactam from a wasp-associated Streptomyces sp. Org. Lett. 2011, 13, 752-755. [CrossRef] [PubMed]

15. Kurz, M.; Schmieder, P.; Kessler, H. HETLOC, an efficient method for the determination of heteronuclear long-range coupling of heteronuclei in natural abundance. Angew. Chem. Int. Ed. 1991, 30, 1329-1331. [CrossRef]

16. Matsumori, N.; Kaneno, D.; Murata, M.; Nakamura, H.; Tachibana, K. Stereochemical determination of acyclic structures based on carbon-proton spin-coupling constants. A method of configuration analysis for natural products. J. Org. Chem. 1999, 64, 866-876. [CrossRef] [PubMed]

17. Félix, F.; Seco, J.M.; Quiñoá, E.; Riguera, R. Determining the absolute stereochemistry of secondary/secondary diols by ${ }^{1} \mathrm{H}$ NMR: Basis and applications. J. Org. Chem. 2005, 70, 3778-3790.

18. Pauli, G.F.; Chen, S.-N.; Lankin, D.C.; Bisson, J.; Case, R.J.; Chadwick, L.R.; Gödecke, T.; Inui, T.; Krunic, A.; Jaki, B.U.; et al. Essential parameters for structural analysis and dereplication by ${ }^{1} \mathrm{H}$ NMR Spectroscopy. J. Nat. Prod. 2014, 77, 1473-1487. [CrossRef] [PubMed]

19. Friebolin, H. Basic One- and Two- Dimensional NMR Spectroscopy, 4th ed.; Wiley-VCH: Weinheim, Germany, 2011.

20. Fujihara, M.; Muroi, M.; Tanamoto, K.; Suzuki, T.; Azuma, H.; Ikeda, H. Molecular mechanisms of macrophage activation and deactivation by lipopolysaccharide: roles of the receptor complex. Pharmacol. Ther. 2003, 100, 171-194. [CrossRef] [PubMed]

21. Rietschel, E.T.; Brade, H. Bacterial endotoxins. Sci. Am. 1992, 267, 54-61. [CrossRef] [PubMed]

22. Sweet, M.J.; Hume, D.A. Endotoxin signal transduction in macrophages. J. Leukoc. Biol. 1996, 60, 8-26. [PubMed]

23. Napolitano, J.G.; Lankin, D.C.; Graf, T.N.; Friesen, J.B.; Chen, S.-N.; McAlpine, J.B.; Oberlies, N.H.; Pauli, G.F. HiFSA fingerprinting applied to isomers with near-identical NMR spectra: The silybin/isosilybin case. J. Org. Chem. 2013, 78, 2827-2839. [CrossRef] [PubMed]

24. Napolitano, J.G.; Lankin, D.C.; McAlpine, J.B.; Niemitz, M.; Korhonen, S.-P.; Chen, S.-N.; Pauli, G.F. Proton fingerprints portray molecular structures: enhanced description of the $1 \mathrm{D}{ }^{1} \mathrm{H}$ NMR spectra of small molecules. J. Org. Chem. 2013, 78, 9963-9968. [CrossRef] [PubMed]

25. Nam, J.-W.; Phansalkar, R.S.; Lankin, D.C.; Bisson, J.; McAlpine, J.B.; Leme, A.A.; Vidal, C.M.P.; Ramirez, B.; Niemitz, M.; Bedran-Russo, A.; et al. Subtle chemical shifts explain the NMR fingerprints of oligomeric proanthocyanidins with high dentin biomodification potency. J. Org. Chem. 2015, 80, 7495-7507. [CrossRef] [PubMed]

26. Xue, C.; Tian, L.; Xu, M.; Deng, Z.; Lin, W. A new 24-membered lactone and a new polyene $\delta$-lactone from the marine bacterium Bacillus marinus. J. Antibiot. 2008, 61, 668-674. [CrossRef] [PubMed]

27. Osada, H.; Koshino, H.; Isono, K.; Takahashi, H.; Kawanishi, G. Reveromycin A, a new antibiotic which inhibits the mitogenic activity of epidermal growth factor. J. Antibiot. 1991, 44, 259-261. [CrossRef] [PubMed]

28. Michel, K.H.; Demarco, P.V.; Nagarajan, R. The isolation and structure elucidation of macrocyclic lactone antibiotic, A26771B. J. Antibiot. 1977, 30, 571-575. [CrossRef] [PubMed]

(C) 2017 by the authors; licensee MDPI, Basel, Switzerland. This article is an open access article distributed under the terms and conditions of the Creative Commons Attribution (CC BY) license (http:/ / creativecommons.org/licenses/by/4.0/). 